\title{
POST-MORTEM CORONARY ARTERIOGRAPHY AND ITS CORRELATION WITH ELECTROCARDIOGRAPHY
}

\author{
BY \\ DAVID WEITZMAN \\ From the Department of Cardiology, Saint Bartholomew's Hospital, London \\ Received June 4, 1963
}

Myocardial anoxia may arise in one of three ways. There may be narrowing and obstruction of the coronary arteries, or the oxygen-carrying power of the blood may be reduced, or there may be relative impairment because of the increased demands of a great bulk of muscle. Under such circumstances, a collateral circulation develops; and Schlesinger (1938), Blumgart, Schlesinger, and Davis (1940), and Zoll, Wessler, and Blumgart (1951) have demonstrated anastomotic channels between right and left coronary arteries in these three conditions of coronary disease, anæmia, and ventricular hypertrophy. Vastesaeger et al. (1957) have been able to show that such channels are present from an early age and suggest that their presence or absence is congenital: this possibility had also been postulated by Prinzmetal et al. (1947).

The portions of the electrocardiogram most affected by any such disturbance in coronary supply are the $\mathrm{S}-\mathrm{T}$ segment and $\mathrm{T}$ wave. These represent repolarization and recovery of the muscle, processes that must be largely affected by the amount of oxygen available.

This investigation was undertaken in order to study the vascularization of the myocardium in different conditions (with particular reference to the distribution of the small vessels) and to correlate this with electrocardiographic patterns recorded during life.

\section{METHOD}

The coronary arteries were studied by post-mortem angiography, using a modification of the technique described by Shillingford (1950). The heart was removed and the coronary arteries were cannulated. They were then injected, by hand pressure, with a suspension either of bismuth oxychloride in gelatin or barium sulphate (micropaque). The particle size was such that capillaries were not entered (Shillingford, 1950). Thin sections were then cut from the walls of both right and left ventricles and $x$-ray pictures were taken on fine-grain film (Kodaline). These were subsequently magnified so that the distribution of the small coronary arteries could be seen in detail.

There was much wastage of material. If 24 hours or more have elapsed between death and necropsy, the coronary arteries may rupture under the pressure of the injection. The arteries may also be damaged during removal of the parietal pericardium. In some cases of gross left ventricular hypertrophy satisfactory filling was not obtained because of the firmness and post-mortem contraction of the muscle.

Technically satisfactory injections were made in 66 cases: 41 were from patients without evidence of heart disease during life, and 17 of these had come from cases of anæmia with a hæmoglobin of 70 per cent or less. The anæmia was often very low (hæmoglobin of $30 \%$ or less) because of chronic leukæmia. There were 25 patients with cardiac lesions, consisting of 9 with ischæmic heart disease, 9 with left ventricular hypertrophy (hypertension, aortic valve lesions), 3 with right ventricular hypertrophy alone (mitral stenosis), 2 with mitral and aortic valve disease producing hypertrophy of both ventricles, and 2 with cardiac myopathies. Ages ranged from 9 to 79 years in the group without heart disease and from 10 months to 72 years in the cases with heart disease. 
The following were used as criteria of arterial abnormality: proliferation of small vessels, giving the appearance of increased vascularity (Shillingford, 1950), and the development of a subendocardial plexus of arteries in the affected ventricle (Fulton, 1956). The normal and abnormal patterns are illustrated in Fig. 1 and 2.

Electrocardiograms had been recorded (during life) in 41 cases-20 with and 21 without heart disease.

\section{RESUlTS}

The incidence of proliferation of small vessels, giving the appearance of increased vascularity, is shown in Table I. This pattern was frequently found in "normal" hearts, in people over the age of 40: under this age increased vascularity was seen in 2 patients with hepatic cirrhosis who had had a portacaval shunt performed. Increased vascularity was the rule in anæmia, ischæmic heart disease, and conditions producing ventricular hypertrophy, irrespective of age or the state of coronary vessels.

When no cardiac lesion was present, the left ventricular wall was nevertheless sometimes thickened and heart weight was increased above normal limits. In the anæmic cases this may have been due either to hypertrophy or œdema. In the older "normals" it could have been due to fibrosis from a degree of coronary atheroma insufficient to cause symptoms or electrocardiographic abnormalities. (Unfortunately, histological studies were not carried out.) Increased vascularity was commoner in hearts with such thickening. There were 19 of these in the 41 "normal" plus anæmic cases, and 15 showed increased vascularity as compared with 12 of the 22 with a normal left ventricular wall.

A subendocardial plexus was seen only in cases with increased vascularity of the left ventricle (Table II). In all hearts with increased vascularity, this followed the same pattern regardless of whether they were "normal" or whether a cardiac lesion was present.

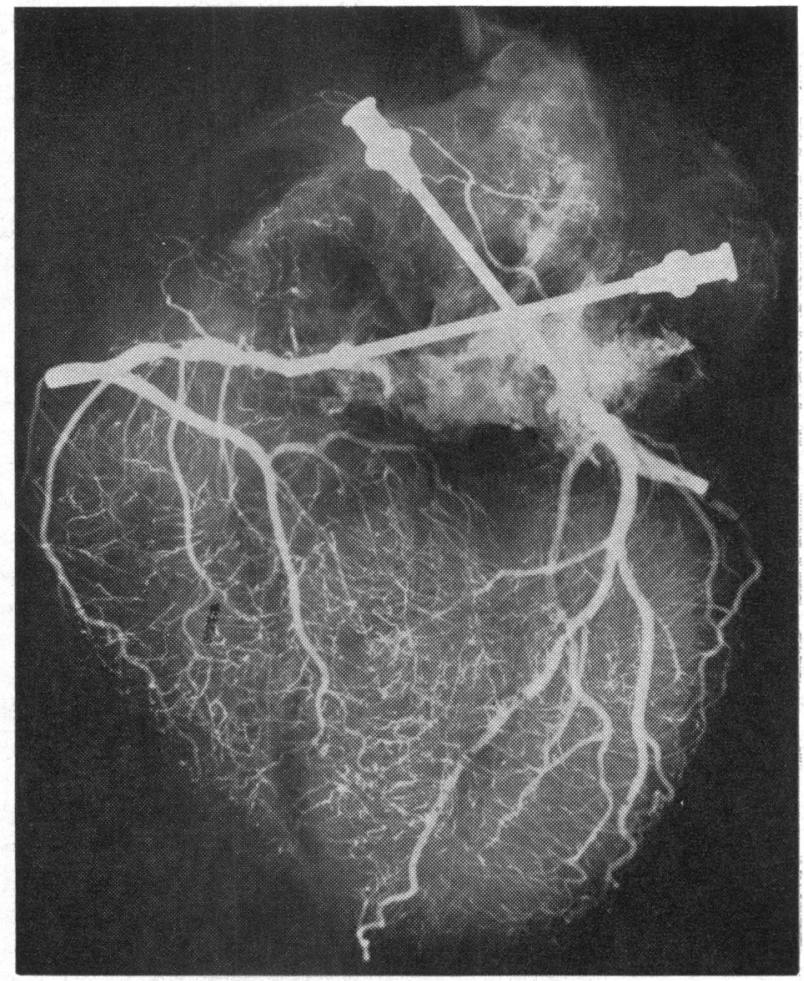

Fig. 1.-Normal coronary arteriogram. (Reproduced from Brit. med.J. (1959) 2, 162, by permision of the Editor.)

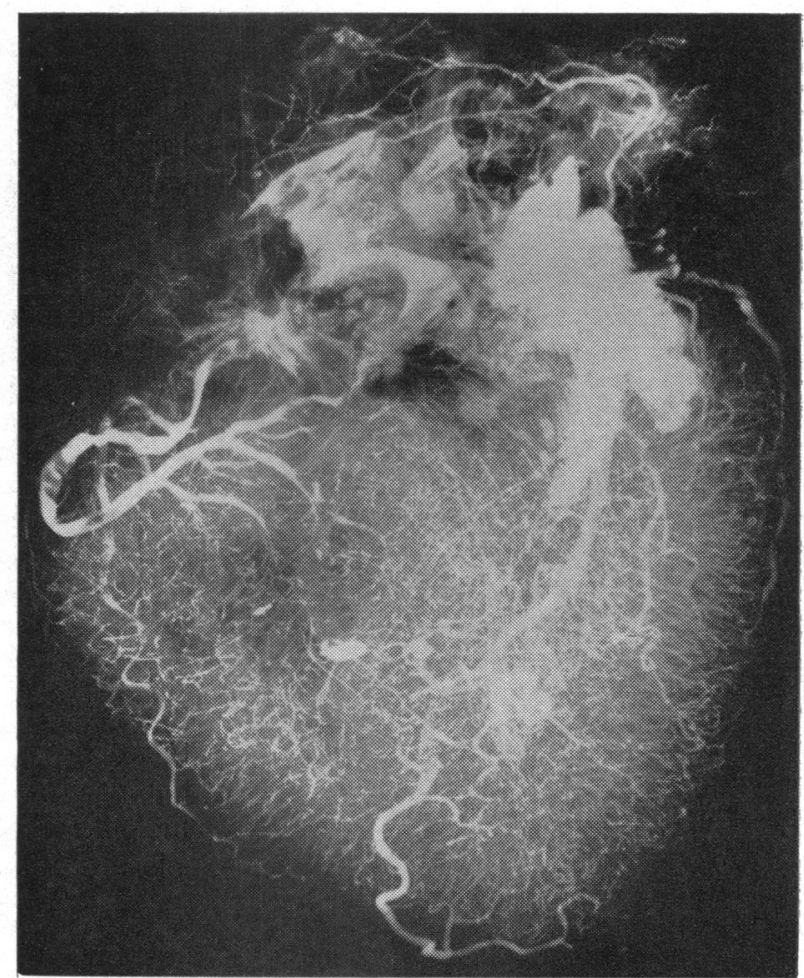

FIG. 2.-Extensive small-artery anastomotic pattern. (Reproduced from Brit. med. J. (1959), 2, 162, by permission of the Editor.) 
TABLE I

INCREASEd Vascularity OF SMall Vessels

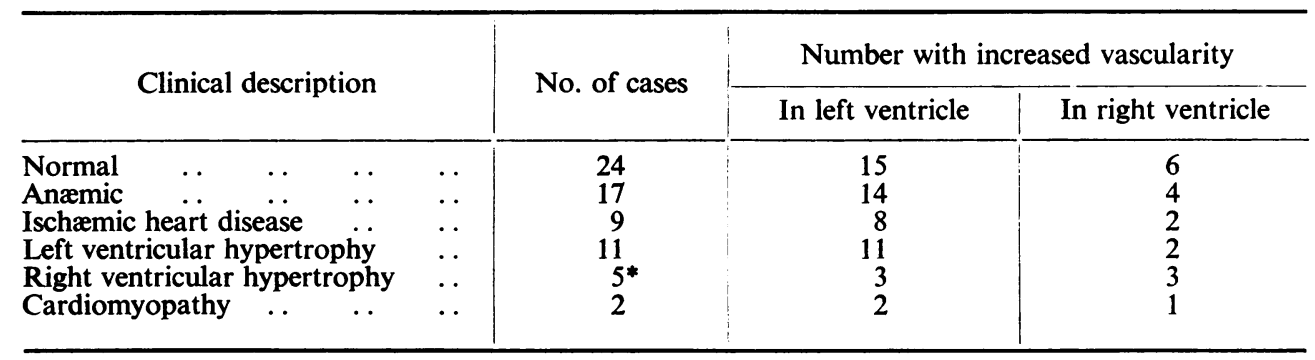

* These numbers include the 2 with hypertrophy of both ventricles.

TABLE II

The Subendocardial Plexus in the Left Ventricle

\begin{tabular}{|c|c|c|c|}
\hline & & No. of cases & $\begin{array}{c}\text { No. with } \\
\text { subendocardial plexus }\end{array}$ \\
\hline $\begin{array}{llll}\text { Normal } & \ldots & \ldots & \ldots \\
\text { Anæmic } & \ldots & \ldots & \ldots \\
\text { Ischæmic } & \ldots & \ldots & \ldots \\
\text { Left ventricular hypertrophy } \\
\text { Cardiomyopathy } & \ldots\end{array}$ & $\begin{array}{l}\cdots \\
\cdots \\
\cdots \\
\ldots\end{array}$ & $\begin{array}{r}15 \\
14 \\
9 \\
11 \\
2\end{array}$ & $\begin{array}{r}11 \\
8 \\
6 \\
7 \\
2\end{array}$ \\
\hline
\end{tabular}

This was seen only in cases with increased vascularity.

Examination of the magnified photographs of thin slices of ventricular muscle revealed that the small arteries became dilated and tortuous as they neared the endocardial surface instead of tapering in the normal manner (Fig. 3 and 4).

The appearance of the small vessels in these sections corresponds to the distribution of the larger arteries in Fulton's sections of the entire heart. These dilated and tortuous terminal branches form the subendocardial plexus that he described.

Correlation with Electrocardiogram. The electrocardiographic findings in relation to the vascular pattern are set out in Table III. In addition to the patients with heart disease, four without evidence of this during life had ischæmic electrocardiograms (Fig. 5); they have already been discussed in a previous publication (Weitzman and Smith, 1959). It was apparent that an increase in

TABLE III

\begin{tabular}{|c|c|c|c|c|c|c|}
\hline Heart & & & $\begin{array}{c}\text { Cardiogram } \\
\text { normal }\end{array}$ & $\begin{array}{c}\text { Increased } \\
\text { vascularity }\end{array}$ & $\begin{array}{c}\text { Cardiogram } \\
\text { abnormal }\end{array}$ & $\begin{array}{l}\text { Increased } \\
\text { vascularity }\end{array}$ \\
\hline $\begin{array}{l}\text { Normal, over } 50 \text { years } \\
\text { Anæmia } . . \\
\text { Ischæmic heart disease .. } \\
\text { Ventricular hypertrophy } \\
\text { Cardiomyopathy }\end{array}$ & $\begin{array}{l}\cdots \\
\cdots \\
\cdots \\
\cdots\end{array}$ & $\begin{array}{l}\cdots \\
\cdots \\
\cdots \\
\cdots\end{array}$ & $\begin{array}{l}6 \\
8 \\
0 \\
0 \\
0\end{array}$ & $\begin{array}{r}4 \\
6 \\
- \\
-\end{array}$ & $\begin{array}{r}4^{*} \\
1^{*} \\
9 \\
11 \\
2\end{array}$ & $\begin{array}{r}4 \\
1 \\
9 \\
11 \\
2\end{array}$ \\
\hline
\end{tabular}

* These tracings showed ischæmic changes (see Fig. 5). 


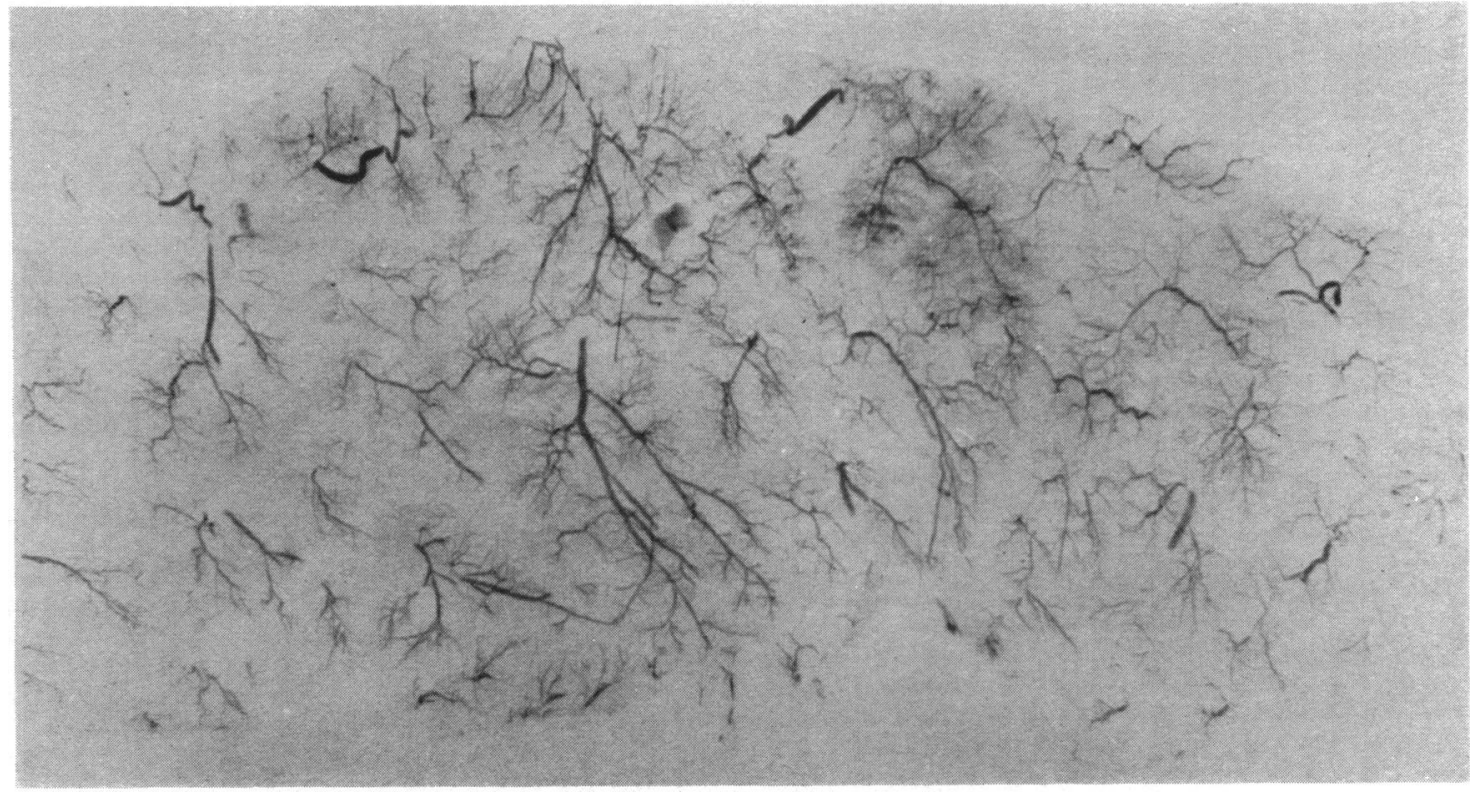

Fig. 3.-Magnified photograph of a thin section of normal ventricular muscle after coronary arteriography. Note how the vessels taper towards the endocardial surface.

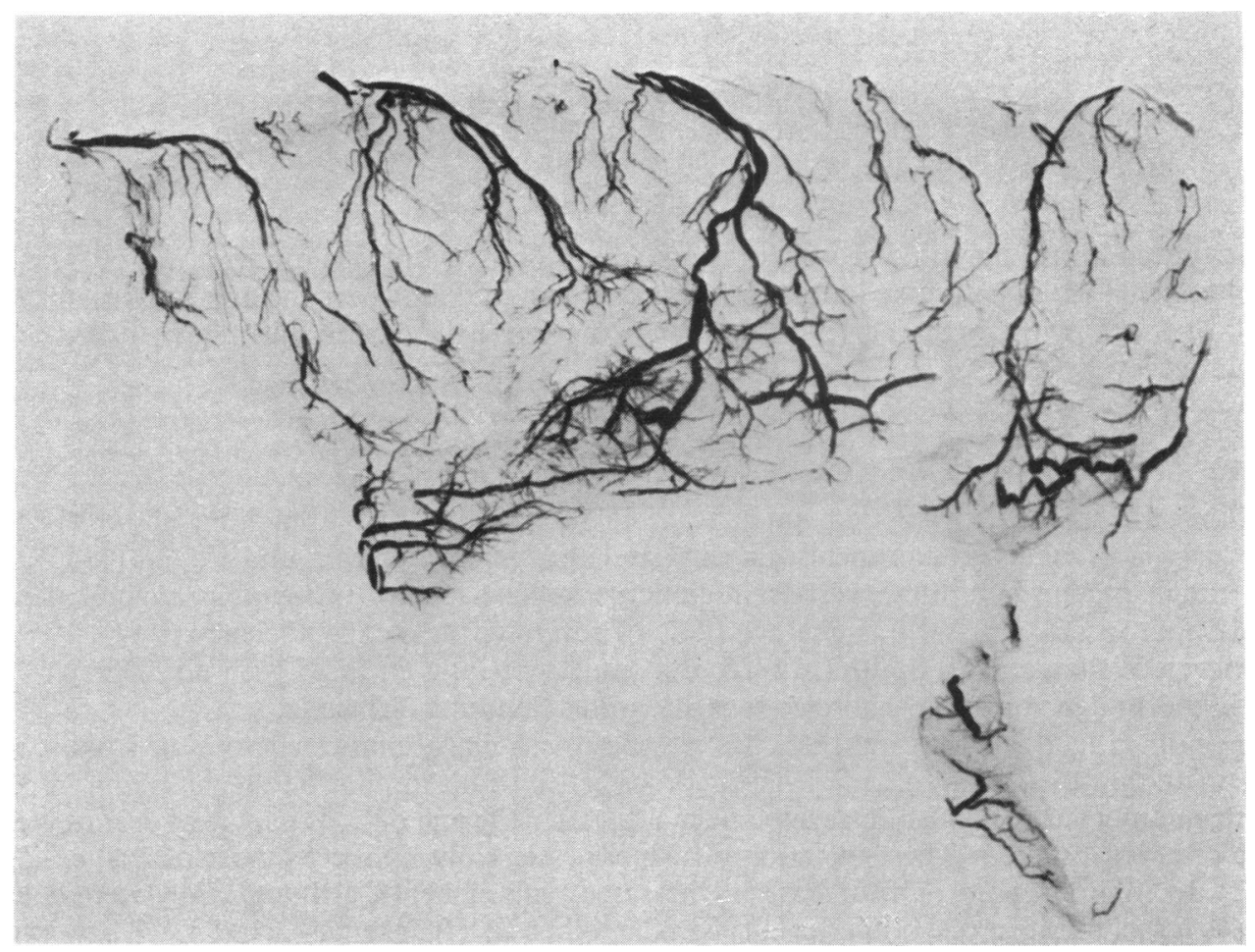

FIG. 4.-A thin section of a hypertrophied left ventricle, showing dilated tortuous sub-endocardial arteries. 
vascularity was invariable in these with abnormal cardiograms but this increase was present also in 10 of 14 patients with no cardiac lesion and normal tracings. However the normal patients were all aged 50 or more, with some degree of coronary atheroma: the 8 with anæmia had died with low hæmoglobin levels ( $40 \%$ or less).

\section{Discussion}

Shillingford (1950) showed that an increase in the number and branching of small coronary vessels was the usual accompaniment of ageing and coronary atheroma; and Fulton (1956) demonstrated much increase in these vessels in patients suffering from intractable anginal pain. He described this vascular pattern as characteristic of severe coronary insufficiency.

However, Weitzman and Smith (1959) found similar patterns in cases with no history of angina during life although some had had electrocardiograms denoting ischæmia.

The findings in this series indicate that a widespread anastomotic network of small coronary vessels, including the subendocardial plexus described by Fulton, is a frequent finding in diseased hearts from any cause and also in severe anæmia. After the age of 50 it may also occur even in the absence of heart disease. These injection results are essentially similar to those of Zoll et al. (1951) in regard to intercoronary anastomoses in the same type of heart, although they were concerned more with larger anastomotic branches between the right and left coronary arteries. They concluded that the development of anastomotic channels was a non-specific response to a relatively insufficient blood supply, whether from coronary artery narrowing, hypertrophy of the ventricular muscle, 
anæmia, or any combination of these factors. In the present series, ageing alone, with its accompanying coronary atheroma, was found to be a sufficient stimulus to the development of this anastomotic network even when the coronary disease had been insufficient to cause ill health.

It might be thought that the appearance in these cases is artificial, the force of injection having filled channels that do not function during life. The appearance of the terminal branches in the magnified sections, however, suggests that this is not so: these dilated vessels seen only in hearts with increased vascularity would have had a low resistance during life, and would therefore fill during coronary flow. Vastesaeger et al. (1957) thought that these anastomotic channels were present developmentally from early life. Prinzmetal et al. (1948) pointed out that the fall in pressure distal to any narrowing of a main coronary artery would produce a gradient favourable to flow from other coronary arteries through existing anastomotic channels. It appears that dilatation of such channels may arise also from the stimulus of relative coronary insufficiency occurring as the result of the other conditions studied.

It is of some interest that all the cardiographic abnormalities concern the $\mathrm{S}-\mathrm{T}$ segment and $\mathrm{T}$ wave. Such abnormalities are found in the electrocardiogram in coronary disease, ventricular hypertrophy, anæmia, and the cardiomyopathies although they may differ in their individual configuration. It is suggested that these patterns may be related to the vascular pattern. The $S-T^{2}$ segment and $\mathrm{T}$ wave represent recovery from contraction and repolarization; these processes are dependent upon blood supply. It is therefore conceivable that the normal appearance of the S-T segment and $\mathrm{T}$ wave may be related to an orderly oxygen distribution throughout the myocardium, attained through the orderly branching of the normal coronary tree. With widespread proliferation of the small vessels as seen in Fig. 2, however, this normal oxygen gradient may not be present: different areas of the myocardium may repolarize in a haphazard manner, producing alterations of the S-T segment and $T$ wave. Such a relation was demonstrated experimentally by Zao, Yen, and Herrmann (1959). They ligated coronary branches in dogs and produced S-T segment elevation in tracings from an electrode placed between pink and cyanotic areas of muscle. Rosen and Gardberg (1957) have drawn attention to S-T abnormalities produced in healthy hearts by tachycardia, and attributed these to alteration of the normal gradient of repolarization: it is possible that similar alterations may be mediated through the abnormal small-vessel distribution shown in Fig. 2. This may be one factor in the similarities of the abnormal repolarization pattern of the electrocardiogram in different disorders, viz. ischæmia, ventricular hypertrophy, anæmia, and cardiomyopathy.

The existence of this vascular pattern in hearts with coronary atheroma insufficient to cause angina during life (although it may alter the cardiogram) was pointed out by Weitzman and Smith (1959). This casts doubt on Fulton's (1956) hypothesis that the proliferation of small vessels is necessarily a response to severe ischæmia, or that it is always associated with severe and intractable anginal pain. It seems rather to be a natural protective reaction that develops pari passu with coronary atheroma (given that the channels pre-exist, as Vastesaeger et al. suggest), thus providing a low-resistance end-arteriolar bed that compensates for narrowing of the main coronary arteries. Anginal pain and myocardial necrosis may nevertheless occur despite this extensive vascularization of the myocardium because occlusion of the main coronary trunks may make the perfusing pressure inadequate even for this low-resistance bed. This bears out the views of Blumgart, Schlesinger, and Zoll (1941) who found that the main coronary trunks in older patients with and without angina differed only in the number of occlusions, rather than as regards their presence or absence.

This profuse vascularization of the myocardium in patients with angina questions the rationale of surgical procedures such as omentopexy and poudrage for its relief. It is difficult to see any advantage in anastomosing omental fat, which is only another tissue with a profuse small-vessel bed, or in promoting further small-vessel proliferation by provoking pericardial adhesions. It seems more logical to try and increase the head of pressure by which the existing large vascular bed is supplied. To this end, coronary disobliteration or, if surgically feasible, the anastomosis of an artery such as the internal mammary, directly to the left coronary artery (rather than simply implanting it into the myocardium by the Vineberg (1952) technique), might be more helpful. 


\section{SUMMARY}

The coronary arterial pattern was demonstrated at necropsy by radio-opaque arteriography in subjects with and without heart disease. Proliferation of small anastomotic channels was found in patients with coronary atheroma, anæmia, and ventricular hypertrophy.

It is suggested that this redistribution of coronary flow alters the gradient of myocardial repolarization and causes the $S-T$ segment and $T$ wave abnormalities seen in the electrocardiogram in these disorders.

\section{REFERENCES}

Blumgart, H. L., Schlesinger, M. J., and Davis, D. (1940). Studies on the relation of the clinical manifestations of angina pectoris, coronary thrombosis, and myocardial infarction to the pathological findings. Amer. Heart J., 19,1 . - $\frac{1}{\text { Ass., 116, } 91 \text {. }}$. A. M. (1941). Angina pectoris, coronary failure and acute myocardial infarction. J. Amer. med.

Fulton, W. F. M. (1956). Chronic generalized myocardial ischæmia with advanced coronary artery disease. Brit. Heart $J ., 18,341$.

Prinzmetal, M., Bergman, H. C., Kruger, H. E., Schwartz, L. L., Simkin, B., and Sobin, S. S. (1948). Studies on the coronary circulation. III. Collateral circulation of beating human and dog hearts with coronary occlusion. Amer. Heart J., 35, 689.

-, Simkin, B., Bergman, H. C., and Kruger, H. E. (1947). Studies on the coronary circulation. II. The collateral circulation of the normal human heart by coronary perfusion with radioactive erythrocytes and glass spheres. Amer. Heart J., 33, 420.

Rosen, I. L., and Gardberg, M. (1957). The effects of nonpathological factors on the electrocardiogram. Amer. Heart J., 53, 494 and 711.

Schlesinger, M. J. (1938). An injection plus dissection study of coronary artery occlusions and anastomoses. Amer. Heart J., 15, 528.

Shillingford, J. P. (1950). The coronary arteries. Clin. J., 79, 258.

Vastesaeger, M. M., Van der Straeten, P. P., Friart, J., Candaele, G., Ghys, A., and Bernard, R. M. (1957). Les anastomoses intercoronariennes telles qu'elles apparaissent à la coronarographie post mortem. Acta cardiol. (Brux.), 12, 365.

Vineberg, A. (1952). Treatment of coronary artery insufficiency by implantation of the internal mammary artery into the left ventricular myocardium. J. thorac. Surg., 23, 42.

Weitzman, D., and Smith, E. B. (1959). Ischæmic electrocardiograms in symptomless men; with a note on the serum lipoproteins. Brit. med. J., 2, 162.

Zao, Z. Z., Yen, M., and Herrmann, G. R. (1959). Relation between S-T segment elevation and experimental myocardial oxygen gradient. Amer. J. Physiol., 196, 207.

Zoll, P. M., Wessler, S., and Blumgart, H. L. (1951). Angina pectoris; a clinical and pathologic correlation. Amer. J. Med., 11, 331. 